\title{
Crafting Strategy That Measures Up
}

\author{
Kwaku Ahenkora (Corresponding author) \\ Christian Service University College \\ PO Box 3310, Kumasi, Ghana \\ Tel: 233-447-930-461-711/233-542-728-616Ｅ-mail: k.ahenkora@yahoo.co.uk \\ Ofosuhene Peasah \\ Department of Computer Science, Kwame Nkrumah University of Science \& Technology \\ PMB, Kumasi, Ghana \\ Tel: 233-244-263-434Ｅ-mail: Kpeasah@yahoo.com
}

$\begin{array}{ll}\text { Received: November 30, } 2010 & \text { Accepted: February 14, } 2011 \quad \text { Published: October 1, } 2011 \\ \text { doi:10.5539/ijbm.v6n10p278 } & \text { URL: http://dx.doi.org/10.5539/ijbm.v6n10p278 }\end{array}$

\begin{abstract}
The strategic management literature is replete with seldom-tested directives on crafting strategy. This study used corporate historical analysis of Proctor and Gamble $(\mathrm{P} \& \mathrm{G})$ to examine the extent to which the company's near decade (2000-2009) strategies reflect the theoretical rationale of Thompson and Strickland's popular textbook's '10 Commandments' of crafting strategy. P\&G attributed the decade's performance to the choices it made by designing the company to lead with clear strategies, core strengths needed to win in the industry, rigorous cash and cost discipline and diversity of leadership. P\&G's strategy partially reflected the predominantly economic themes of the 10 commandments. The company also leveraged dynamic capabilities and harnessed alliance competence, concepts embedded in the evolution of strategic management.
\end{abstract}

Keywords: Crafting strategy, Ten commandments, Core competence, Proctor and Gamble

\section{Introduction}

The need to deliver on clear strategic choices in today's hypercompetitive business and uncertain environment is greater than ever. Strategic management, therefore, has become an expectation, not only on the part of the company but also the individual manager. Of the topic areas taught in business schools on a global scale and the various discourses and practices that are involved in managing organisations, private or public, few can be seen as more significant than strategy in its various forms (Knight and Mueller, 2004). The implications of a poorly developed and poorly implemented approach to thinking and planning led some writers to suggest that many companies have lost the art of strategy-making (de Kare Silver, 1997). Over the past 50 years a considerable amount has been written about strategy and from this a variety of definitions and strategic perspectives have emerged.

Mintzberg (1994) identified ten views of the strategy process and how they have developed. These schools of thought are the design, planning, positioning, entrepreneurial, cognitive, learning, power, cultural, environmental and configuration. Whittington (1993) suggested that there are four principal or generic approaches to strategy formulation. These are the classical, evolutionary, processual and systemic approaches. Implicit in these approaches is the concept that strategies are both deliberate and emergent. Giligan and Wilson (2003) proposed that organisations should pursue 'umbrella strategies' where the broad outlines are deliberate while the details are allowed to emerge within them. An organisation with a well-articulated strategy can achieve sustained competitive advantage over those organisations that lack strategic vision (Prahalad and Hamel, 1990; Porter, 1987).

Although there are a potentially unlimited variety of effective corporate strategies it has been suggested that if executives benchmarked their strategies aggressively as they do their operations, most would discover that their strategies are far from first class (Collis and Montgomery, 1998). Thompson and Strickland (2001), in their 
popular strategic management textbook used by business schools around the world, therefore, proposed the ten commandments to serve as useful guides for developing sound strategies:

1. Place top priority on crafting and executing strategic moves that enhance the company's position for the long term

2. Be prompt in adapting to changing market conditions, unmet customer needs, buyer wishes for something better, emerging technological alternatives, and new initiatives of competitors

3. Invest in creating a sustainable competitive advantage

4. Avoid strategies capable of succeeding only in the most optimistic circumstances

5. Don't underestimate the reactions and the commitment of rival firms

6. Consider that attacking competitive weakness is usually more profitable and less risky than attacking competitive strength

7. Be judicious in cutting prices without an established cost advantage

8. Strive to open up very meaningful gaps in quality or service or performance features when pursuing a differentiation strategy

9. Avoid 'stuck in the middle' strategies that represent compromise between lower costs and greater differentiation and between broad and narrow market appeal

10. Be aware that aggressive moves to wrest market share away from rivals often provoke retaliation in the form of a marketing 'arms race' or price war- to the detriment of everyone's profits.

Moncrieff (1999) argued that to have a thought-provoking insight into strategy, one needs to determine whether strategy is making a difference; as the popular business literature on strategic management is replete with prescriptions and directives with regard to successful strategic recipes (Vorberda, 2004). This study, therefore, looks at the extent to which Thompson and Strickland's guidelines help explain P\&G's performance.

\section{Match-up test}

Thompson and Strickland's proposed guidelines of crafting successful business strategies were distilled out of experience but the attributes are assumed to have a generic application. The study applied Moncrieff's test for finding out whether a company's strategy is making a difference to $P \& G$, by reviewing the extent to which 2009s position was articulated in some form of strategy in 2000 (and thereafter) and the company's perspective of the drivers of performance. The study then examined the extent to which P\&G's management's perspectives of its near decade strategic performance reflect the theoretical rationale of Thompson and Strickland's guidelines for crafting business strategy. While the use of Moncrieff's test provides a thought-provoking insight into strategy, it limits the information to the intentions of only the top management.

\section{Corporate historical perspective}

\subsection{Strategic choices}

This section provides corporate historical account of $P \& G$ for the period 2000-2009. In 2000 there was a change of leadership at $P \& G$. At the time, the company faced some of the most demanding challenges in its history. The company made the strategic choices necessary to get $P \& G$ back on track to sustainable growth'. Three strategic choices drove virtually all of P\&G's top-line, bottom-line, and shareholder growth this decade (P\&G, 2009). The first choice focused on P\&G's core businesses and leading billion-dollar brands; to win with the biggest and strongest retail customers, and to win in the most important countries. Nearly $80 \%$ of P\&G's sales and profit growth this decade came from 10 businesses and $75 \%$ of sales and profit growth came from P\&G's leading billion-dollar brands.

The second choice was to shift the business portfolio to more Beauty and Personal Care businesses. The percentage of $P \& G$ sales in more capital-intensive Paper and Food businesses went from $42 \%$ at the beginning of the decade to $25 \%$. At the same time, the percentage of sales in more asset-efficient, faster-growing, higher-margin businesses increased from $18 \%$ to $33 \%$ over the same period. Beauty, Personal Care and Health Care have accounted for more than $60 \%$ of sales and profit growth in the past eight years.

The third strategic choice was to extend the availability and affordability of $P \& G$ brands to more low-income consumers, particularly in developing markets. The company grew sales in developing markets from $20 \%$ at the beginning of the decade to $32 \%$ at the end with these markets contributing $42 \%$ of the company's sales growth and $29 \%$ of profit growth. On an aggregate basis, $P \& G$ has a $19 \%$ share in developing markets, over five times 
the average developing-market sales of its major competitors, and is growing steadily by about half a share point a year.

With these three strategies $P \& G$ delivered strong growth; sales doubled over the past decade and core earnings-per-share grew 12\% on average since 2001 (Table 1). P\&G has shown that the need to change creates choices and strategy reflects managerial choices among alternatives and signals organisational commitment to particular products, markets, competitive approaches, and ways of operating the enterprise (Thompson and Strickland, 2001). Fahey and Randall (2001) have indicated that the choices organisation's make depend to a large extent on their understanding of current and potential change and their capacity to anticipate, create and leverage change in scope (i.e. choice of products and customers), posture (how aggressive it competes in its chosen business) and goals (the choice of what attainment it pursues).

\subsection{Capabilities}

In addition to clear where-to-play strategies, the company also chose to focus on five core strengths that are required to win in the consumer products industry: consumer understanding, brand-building, innovation, go-to-market capability, and scale. $P \& G$ was designed to lead in each of these areas. This resulted in virtually all the organic sales growth delivered in the past nine years coming from new brands and new or improved product innovation. The company invested two times more, on average, to strengthen innovation capability than its major competitors and multiplied internal innovation capability with a global network of innovation partners outside P\&G. Currently, more than half of all product innovation coming from $P \& G$ includes at least one major component from an external partner. Over the past 14 years, P\&G has had 114 top 25 Pacesetters - more than the company's six largest competitors combined. $P \& G$ is the brand-building leader of the industry and has built the strongest portfolio of brands in the industry with 23 billion-dollar brands and 20 half-billion-dollar brands. These 43 brands account for $85 \%$ of sales and more than $90 \%$ of profit. Twelve of the billion-dollar brands are the number 1 global market share leaders of their categories. The majority of the remaining brands are number 2 . As a group, P\&G's billion-dollar brands have grown sales at an average rate of $11 \%$ per year for the entire decade. $P \& G$ established industry-leading go-to-market capabilities and is consistently ranked by leading retailers in industry surveys as a preferred supplier and as the industry leader in a wide range of capabilities including clearest company strategy, brands most important to retailers, strong business fundamentals and innovative marketing programs. Over the decade, the company established significant scale advantages as a total company and in individual categories, countries and retail channels. P\&G's scale advantage is driven as much by knowledge sharing, common systems and processes, and best practices as it is by size and scope. These scale benefits deliver consistently superior consumer and shareholder value.

\subsection{Cash and Cost Management}

P\&G's cash productivity - the percentage of earnings that is converted into cash — has averaged over 100\% since the beginning of the decade, consistently among the very best in the industry (Table 2). Cash productivity allowed the company to maintain excellent credit rating, pay a strong dividend every year, and to have the flexibility to invest in the business organically or through mergers and acquisitions. The company relentlessly focused on working-capital management and operated more efficiently with fewer days of receivables outstanding than any consumer products competitor. The company reduced overhead costs as a percentage of sales by more than 300 basis points since 200 . $P \& G$ also focused on increasing productivity in other business areas. At the end of the decade sales per employee and profit per employee increased by $61 \%$ and $162 \%$, respectively, while the productivity of the R\&D organization doubled; the company supports additional increase in sales with virtually the same number of $R \& D$ employees in the company nearly a decade ago. This performance has been attributed to continuous innovation and working with the large and diverse global network of external innovation partners. This productivity discipline ensures that $P \& G$ has the flexibility and the resources to invest in growth even in the most challenging environments.

\subsection{Balancing Near-Term Results and Long-Term Growth}

The recent credit crisis and global recession tested the strength of strategies; the balancing act of short-term results and long term growth. $\mathrm{P} \& \mathrm{G}$ made two critical choices to deal with this macroeconomic environment. The company focused on disciplined cash and cost management and invested in capacity, innovation and consumer value to ensure $P \& G$ was leading and growing market share after the recession. The company focused first on cash and costs to protect the financial foundation of its businesses. It increased prices to recover higher commodity costs and foreign exchange transaction impacts.

The company next focused on innovation and brand-building and identified and funded product innovation and marketing initiatives across the business, with an emphasis on growing profitable value share in P\&G's core 
categories. It also maintained commitment to research and development investments and delivered strong consumer communication programs that emphasized the powerful performance-based value of its products. The company at the end of the decade invested $4 \%$ of sales in capital spending, including funding for new manufacturing capacity to support future growth in new markets. The company's strategy of migrating the manufacturing base closer to the consumers was aimed lowering costs and enabling better value for more consumers. P\&G's performance in fiscal 2009, towards the end of the recession, reflected the success of these choices; the company delivered organic sales and EPS growth and maintained operating margin while delivering strong free cash flow - the financial lifeblood of the business

\section{The 10 commandments and P\&G}

$P$ \& $G$ is globally recognised and a focused (Commandment 9) consumer products marketer that seeks competitive advantage in quality, value-added personal care and personal use products. The company's approach to strategy shows they are among successful companies who tend to have well crafted strategies, which contain a vision and long term mission objectives (Commandment 1 ) of where the company is going, and are equally able to translate the vision into operational actions which enable specific objectives to be achieved and response to change (Commandment 2) made (Ellis and Williams, 1993). The company's performance shows the strong link between the corporate and business strategies: the corporate strategy was aimed at adding value to the operational segments (business units) while business strategies focused on crafting sizeable and sustainable competitive advantage (Commandment 3). It is recognised that corporate strategy adds value through portfolio management, corporate core competencies and enhancing business unit performance (Goold and Campbell, 1987). P \& G has clear cut growth strategies, pursues brand and technological leadership. The distinctiveness of a company's competency lies in its superior skills and superior resources (Prahalad and Hamel, 1990; Collis and Montgomery, 2005). P \& G's managers view their competency in their differentiation (Commandment 8) in a combination of technology, product performance, and marketing (P\& G, 2009). P \& G prides itself as a leader in innovation and uses competency in innovation and updated technology to protect the company from fast imitators (Commandment 4).

$P \& G$ is an aggressive competitor with strategic clarity about where it plays and how it competes in its chosen product markets to achieve superior performance. The company understands the competition and have counter strategies for competing (Commandment 5, 10). P\&G's corporate and business strategies have been designed with sustainable competitive advantage in view. The company clearly understands its global market and positions itself (Commandment 1 ) in the market accordingly. It pursues a strategy of differentiation and also take advantage of its global presence and better pricing because of its better-performing and higher-margin products. To maintain its differentiation the company works to deliver value, not necessarily by being the cheapest but through earning a reputation for high quality products that represent good value for money. For example during the recession of 2009, P\&G maintained a strong business foundation, not through lowering but by increasing the prices of some of its brands. The rational of the increase was to recover higher commodity costs and foreign exchange transaction impacts. Despite price increases, the company held global value shares across the majority of categories, which is a reflection of $\mathrm{P} \& \mathrm{G}$ brands' strength with consumers and retail customers. Although the company knew that increased pricing would lead to market share volatility, and even some short-term share loss; and that higher prices might affect consumption in some more-discretionary categories, they were willing to accept these short-term consequences to maintain investment-grade financial health (P\&G, 2009).

\section{Overview and conclusion}

P\&G's corporate account of its near decade performance depicts the link between strategy and performance, including financial outcomes, and that strategy does make a difference. This corroborates the observation that high-performing enterprises often initiate and lead, not just react and defend and they are always the product of astute, proactive management, rather than the result of lucky breaks or a long run of good fortune (Thompson and Strickland, 2001). P\&G asserts that their business and financial performance is the result of clear choices and extraordinary commitment and capability at every level of the company. There is little evidence to suggest that firms competing in markets which appear to offer attractive opportunities necessarily perform better than those that compete in markets which seem less attractive (Mintzberg, 1994). Sound strategies should show a connection between the firm's capabilities and competitive advantage. Prahalad and Hamel (1990) and Ulrich and Lake (1991) have emphasised the strategic importance of identifying, managing, and leveraging 'core competencies' rather than focusing only on products and markets in crafting business strategy.

Thompson and Strickland's 10 commandments propose that generic strategies are one-dimensional and companies should either seek to develop competitive advantages based on differentiation (being unique) or cost 
(Porter, 1980). Different aspects of this approach has been questioned (Gilbert and Strobel, 1988; Crenshaw et al., 1990) and it has been suggested that in practice managers need to have recourse to all five dimensionsdifferentiation, cost, scope, time and competitive linkages (Ellis and Williams, 1993). P\&G's execution strategies corroborate this perspective. It is apparent that $\mathrm{P} \& \mathrm{G}$ works on the basis of developing multiple sources of competitive advantage which are difficult or costly to replicate and attempts to reconcile the tensions between cost and differentiation. The company's manufacturing strategy recognises the importance of time as an element of competitive advantage and its strategic sourcing initiatives strengthened its competitive linkages (Ellis and Williams, 1993). P\&G's ability to leverage the strength of working with diverse partners across the globe reflects the emerging ideologies on strategy in the decade.

Venkatram and Subramaniam (2002) have suggested that strategy has moved through a series of three eras, each characterised by a dominant set of ideas. Firstly, strategy was viewed as the management of portfolio of businesses where the focus was on industry positioning to gain advantage from scale economies (Porter, 1980, 1985). In the second era, strategy came to be understood in terms of developing a portfolio of capabilities where success was derived from the inimitability of processes and routines within the organisation (Collis and Montgomery, 1990; Porter, 1996; Prahalad and Hamel 1990). In the third era, the 2000s, strategy was conceptualised as a portfolio of relationships whereby position in wider networks of expertise were crucial to competitive advantage (Starkey and Tempest, 2004).

It appears that $P \& G s$ approach to crafting strategy balances the dominant perspectives in the three eras. $P \& G$ has a dynamic approach to crafting strategy to meet the demands of stakeholders and a dynamic environment. At the business strategy level of products and markets, $P \& G$ 's strategy takes on board some aspects of the guiding principles of Thompson and Strickland's 10 commandments of crafting strategy. However, the company also remarkably uses its corporate core competencies to drive business strategy. There is an integrated approach to strategic management where all determinants of firm performance, economic and organisational, work in harmony with each other to create total economic value. This re-emphasises the importance of identifying and leveraging core competencies and products/ markets in crafting successful strategies.

Regarding this work and its potential implications for managers and students, the limitation of corporate analysis of one company should be kept in mind. However, if strategy is a managerial imperative, and if, in order to understand and talk about it academics disintegrate it through theories and guidelines, then strategy appears to be a holistic, continuous process which managers, in practice, treat as an interdependent whole.

\section{References}

Collis, D.J., \& Montgomery, A. (1995). Competing on resources: strategy in the 1990s. Harvard Business Review, July-August, 118-128.

Collis, D.J., \& Montgomery, A. (1998). Creating corporate advantage. Harvard Business Review, 76 (3), 71-83.

Crenshaw, M., Davis, E., and Kay, J. (1990). On being stuck in the middle or good food costs less at Sainsbury's. London Business School Working Paper Series, Number 83, August.

De Kare-Silver, M. (1997). Strategy in crisis: why business urgently needs a completely new approach. McMillan Press. Basingstoke. pp.16

Ellis, J., \& Williams, D. (1983). Corporate strategy and financial analysis. Financial Times. Prentice Hall: Harlow pp. 11-52.

Fahey, L., \& Randall, R.M. (2001). Managing marketplace strategy. In L. Fahey, and R.M. Randall, (Eds), The Portable MBA in Strategy. New York: John Wiley \& Sons, (Chapter 1).

Gilbert, X \& Strebel, P. (1988). Developing competitive advantage. In J. B Quinn, H. Mintzberg, \& M.J. James. The strategy process. Hemel Hempstead: Prentice Hall, pp70-79

Gilligan, C., \& Wilson, R.M.S. (2003). Strategic marketing planning. London: Butterworth Heinemann. Pp48-54.

Goold, M., \& Campbell, A. (1987). Many best ways to make strategy. Harvard Business Review .65 (3):70-76

Grundy, T., \& Brown, L. (2002). Be your own strategy consultant. Demistifying strategic thinking. London:

Hofer, C., \& Schendel, D. (1978). Strategy formulation: analytical concepts. St. Paul, Mn: West

Knight, D., \& Mueller, F. (2004). Strategy as project: overcoming dualisms in the strategy debate. European Management Review, 1:55-61. http://dx.doi.org/10.1057/palgrave.emr.1500001

Mintzberg, H. (1994). The rise and fall of strategic planning. Hemel Hempstead: Prentice-Hall International. 
Moncrieff, J. (1999). Is strategy making a difference? Long Range Planning, 32:273-276. http://dx.doi.org/10.1016/S0024-6301(99)00033-3

P\&G. (2009). Proctor and Gamble. Annual Report. [Online] Available: http://www.Annualreport.pg.com (23 (July 23, 2010).

Porter, M.E. (1987). From competitive advantage to corporate strategy. Harvard Business Review, 65 (3), 43-59.

Porter, M.E. (1996). What is strategy? Harvard Business Review, 74(6):61-79.

Prahalad, C.K., \& Hamel, G.1990. The core competence of the corporation. Harvard Business Review, 68 (3), 79-91.

Thompson Learning.

Thompson, AA., \& Strickland, A.J. (2001). Crafting and executing strategy. (12 ${ }^{\text {th }}$ ed). London: McGraw Hill. Irwin. (Chapter 8).

Ulrich, D., \& Lake, D. (1991). Organisational capability. New York: Wiley. pp. 20-45.

Venkatraman, N., \& Subramaniam, M.2002. Theorising the future of strategy: questions for shaping strategy research in the knowledge economy, In A. Pettigrew, Thomas H. \& Whittington, R. (eds). Handbook of strategy and management. London: Sage. (Chapter 4)

Vorberda, H.W. (2004). Crisis in strategy: fragmentation, integration or synthesis. European Management Review, 1, 35-42. http://dx.doi.org/10.1057/palgrave.emr.1500013

Whittington, R. (1993). What is strategy and does it matter? London: Routledge. (Chapter 1).

Table 1. Financial performance

\begin{tabular}{|l|l|l|}
\hline Selected indicator & 2009 & 2001 \\
\hline Net sales & $\$ 79,029$ & $\$ 38,545$ \\
\hline Gross margin & $\$ 40,131$ & $\$ 17,854$ \\
\hline Net earning margins & 14.3 & 8.4 \\
\hline Net earnings per common share & 4.49 & 1.24 \\
\hline Dividend per common share & 1.64 & 0.64 \\
\hline Research and development expense & $\$ 2044$ & $\$ 1880$ \\
\hline Total assets & $\$ 134,833$ & $\$ 3466$ \\
\hline Shareholders equity & $\$ 63,039$ & $\$ 12673$ \\
\hline
\end{tabular}

Amount in Millions (except per share amounts)

Table 2. Progress against P\&G's goals and strategies

\begin{tabular}{|l|l|l|}
\hline Growth Results (average annual) & Goals & $2001-2009$ \\
\hline Organic sales growth & $4-6 \%$ & $5 \%$ \\
\hline Core earnings per share & $10 \%$ & $12 \%$ \\
\hline Free cash flow productivity & $90 \%$ & $112 \%$ \\
\hline
\end{tabular}

